\title{
Alterations in thyroid hormone levels following growth hormone replacement exert complex biological effects.
}

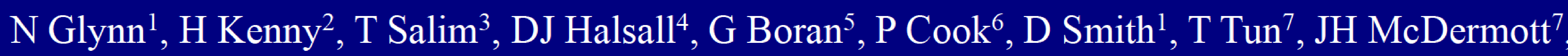 \\ W Tormey ${ }^{8}$, CJ Thompson ${ }^{1}$, B McAdam ${ }^{3}$, D O' Gorman ${ }^{2}$, A Agha $^{1}$
}

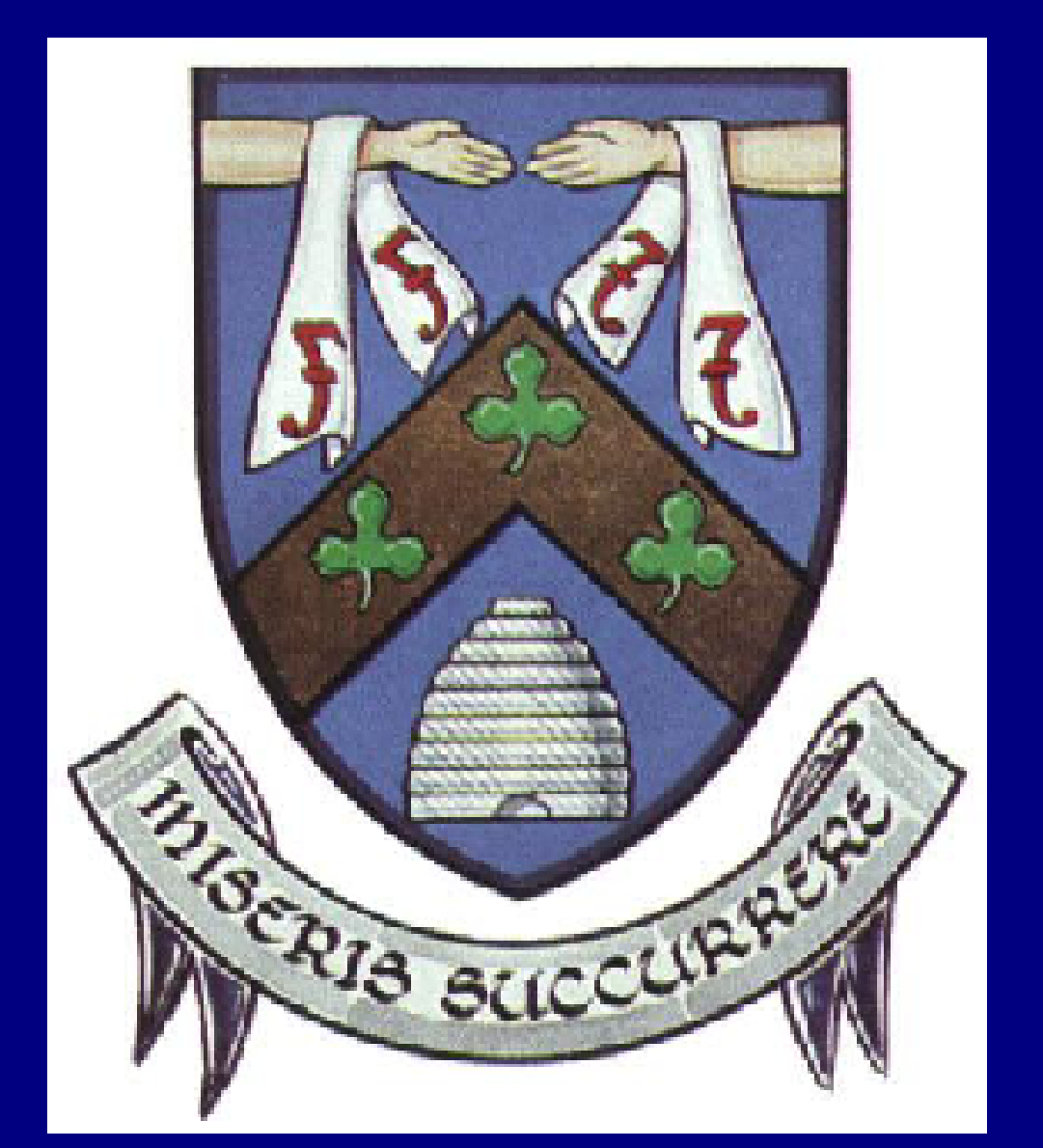

Departments of Endocrinology ${ }^{1}$,Cardiology ${ }^{3}$ and Chemical Pathology ${ }^{8}$, Beaumont Hospital, Dublin, Ireland. School of Health and Human Performance ${ }^{2}$, Dublin City University, Ireland. Department of Clinical Biochemistry ${ }^{4}$, Addenbrooke's Hospital, Cambridge, UK. Department of Clinical Biochemistry ${ }^{5}$, Adelaide and Meath Hospital, Dublin, Ireland. Department of Chemical Pathology ${ }^{6}$, University Hospital Southampton, UK. Department of Endocrinology ${ }^{7}$, Connolly Memorial Hospital, Dublin, Ireland.

\section{INTRODUCTION}

Alterations in the hypothalamic-pituitary-thyroid axis have been reported following growth hormone $(\mathrm{GH})$ replacement, with a decline in circulating $\mathrm{T} 4$ concentration the most consistent finding.

However, the clinical significance of GHinduced alterations in circulating levels of thyroid hormone is unclear.

Concentration of other certain serum proteins and lipoproteins are influenced by minor changes in thyroid status. In addition, resting energy expenditure (REE) and systolic time intervals on echocardiography are very sensitive to circulating thyroid hormone levels.

\section{AIM}

Examine the relationship between changes in serum concentration of thyroid hormones and known biological markers of thyroid hormone action following GH supplementation.

\section{PATIENTS \& METHODS}

We performed a prospective, observational study of adult hypopituitary patients receiving $\mathrm{GH}$ replacement as part of routine clinical care.

Subjects with and without TSH deficiency were included. Other hormones were adequately replaced prior to growth hormone treatment as per standard clinical practice.

\section{Baseline tests performed before $\mathrm{GH}$} supplementation

\section{Thyroid function tests, IGF-1, and basal} pituitary blood tests

Serum markers of thyroid hormone action including ferritin, sex hormone binding globulin (SHBG), creatinine kinase (CK) and lipoproteins.

\section{REE was measured using a ventilated} calorimeter and systolic time intervals were assessed by transthoracic echocardiogram.

GH dose was titrated to achieve an IGF-1 in the upper half of age-related reference range

Tests were repeated after a 3-6 months on a stable dose of GH.

\section{REFERENCES}

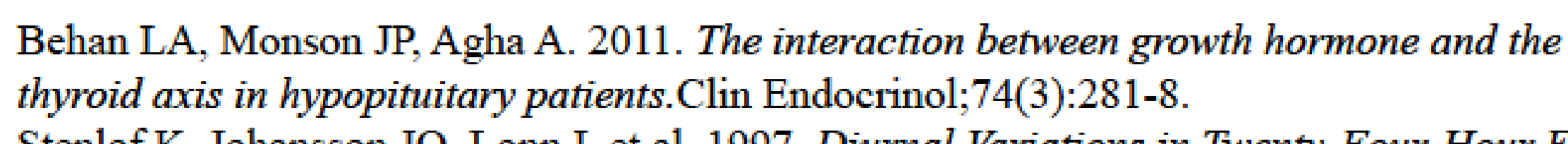
Stenlof K, Johansson JO, Lonn L et al. 1997. Diurnal Variations in Twenty-Four-Hour Energ Expenditure During Growth Hormoin
Endocrinol Metab; 82:1255-1260.

\section{RESULTS}

20 male hypopituitary patients were studied before and after $\mathrm{GH}$ replacement.

Baseline characteristics are outlined in Table 1.

\begin{tabular}{|c|c|c|}
\hline Male/Female & \multicolumn{2}{|l|}{$20 / 0$} \\
\hline \multicolumn{3}{|c|}{ Aetiology of GHD (\%) } \\
\hline - NFPA & \multicolumn{2}{|l|}{$10(50)$} \\
\hline - Prolactinoma & \multicolumn{2}{|l|}{$4(20)$} \\
\hline - Other & \multicolumn{2}{|l|}{$6(30)$} \\
\hline MPHD (\%) & \multicolumn{2}{|l|}{$17(85)$} \\
\hline \multirow[t]{2}{*}{ On Thyroxine (\%) } & \multicolumn{2}{|l|}{$13(65)$} \\
\hline & Median & Range \\
\hline Age (years) & 52.5 & $(21.8-68.6)$ \\
\hline BMI (kg/m2) & 31.34 & $(19.2-49.7)$ \\
\hline GH dose (mg/day) & 0.34 & $(0.15-0.5)$ \\
\hline
\end{tabular}

Table 1. Baseline demographic features.

MPHD Multiple Pituitary Hormone Deficiencies. GHD Growth Hormone Deficiency

Body mass index(BMI) did not change during the study.

Following growth hormone replacement, IGF-1

levels rose significantly $+114.4 \pm 12.3 \mu \mathrm{g} / \mathrm{L}$, $\mathrm{p}<0.0001$.

FreeT4 levels declined as expected $(-1.28 \pm 0.44 \mathrm{pmol} / \mathrm{L}, \mathrm{p}=0.02)$. Reverse T3 levels also fell $(-3.44 \pm 1.42 \mathrm{ng} / \mathrm{dL} ; \mathrm{p}=0.03)$ and freeT3 levels increased significantly $(+0.34 \pm 0.15 \mathrm{pmol} / \mathrm{L}$ $\mathrm{p}=0.03$ ).

REE did not rise as expected with $\mathrm{GH}$ substitution. Also, cardiac systolic time intervals were unchanged

Alterations in serum biomarkers of thyroid hormone action are shown in Table 2. Significant alterations in ferritin, $\mathrm{Cu}$ and caeruloplasmin concentrations were more closely correlated with changes in serum freeT4 rather than IGF-1.

\begin{tabular}{|c|c|c|c|}
\hline $\begin{array}{c}\text { Serum biomarker } \\
\text { of } \mathrm{TH} \text { action }\end{array}$ & $\begin{array}{c}\text { Pre-GH } \\
\text { Mean (SEM) }\end{array}$ & $\begin{array}{c}\text { Post-GH } \\
\text { Mean (SEM) }\end{array}$ & CI; $p$ value \\
\hline Ferritin ng/ml & $87.98(15.01)$ & $61.09(12.75)$ & $\begin{array}{c}-39 \text { to }-3.4 \\
p=0.005^{*}\end{array}$ \\
\hline CK U/L & $154.8(26.77)$ & $149.5(18.81)$ & $\begin{array}{l}-25.00 \text { to } 11.00 \\
p=0.6809\end{array}$ \\
\hline SHBG nmol/L & $35.85(4.263)$ & $34.09(4.117)$ & $\begin{array}{l}-5.960 \text { to } 2.430 \\
p=0.3895\end{array}$ \\
\hline Copper umol/L & $16.99(0.8815)$ & $15.26(0.7878)$ & $\begin{array}{l}-3.089 \text { to }-0.3855 \\
\mathrm{p}=0.0152^{*}\end{array}$ \\
\hline $\begin{array}{l}\text { Caeruloplasmin } \\
\text { g/L }\end{array}$ & $0.2540(0.01229)$ & $0.2305(0.01325)$ & $\begin{array}{l}-0.0451 \text { to }-0.00184 \\
\mathrm{p}=0.0356^{*}\end{array}$ \\
\hline
\end{tabular}

\begin{tabular}{|c|c|c|c|}
\hline $\begin{array}{l}\text { Lipid Fraction } \\
\text { mg/dL }\end{array}$ & $\begin{array}{c}\text { Pre-GH } \\
\text { Mean (SEM) }\end{array}$ & $\begin{array}{c}\text { Post-GH } \\
\text { Mean (SEM) }\end{array}$ & CI; p value \\
\hline Tot. Chol & 192.6(11.58) & $191.3(9.875)$ & $\begin{array}{l}-15.24 \text { to } 12.61 \\
p=0.8435\end{array}$ \\
\hline LDL & 105.1(7.798) & $104.3(6.945)$ & $\begin{array}{l}-9.855 \text { to } 8.355 \\
p=0.8630\end{array}$ \\
\hline HDL & $44.44(2.208)$ & $45.06(1.707)$ & $\begin{array}{l}-2.382 \text { to } 3.632 \\
p=0.6641\end{array}$ \\
\hline Large HDL & $9.500(1.351)$ & $11.25(1.149)$ & $\begin{array}{l}0.2746 \text { to } 3.225 \\
p=0.0232^{*}\end{array}$ \\
\hline Intermediate HDL & $25.5(1.201)$ & $25.5(0.908)$ & $\begin{array}{l}-1.348 \text { to } 1.348 \\
p>0.9999\end{array}$ \\
\hline Small HDL & $9.375(0.978)$ & $8.188(0.634)$ & $\begin{array}{l}-3.005 \text { to } 0.6296 \\
\mathrm{p}=0.1840\end{array}$ \\
\hline Lp (a) nmol/L & $46.64(11.40)$ & $62.08(15.65)$ & $\begin{array}{l}0.0 \text { to } 25.50 \\
\mathrm{p}=0.0034^{*}\end{array}$ \\
\hline
\end{tabular}

Table 3. Alterations in lipid parameters following GH substitution in tandem with alteration in thyroid hormone levels. Data presented for patient $\mathrm{s}$ with MPHD only $(n=17)$

The effect of GH substitution on lipid parameters is shown in Table 3 . The metabolic effects of GH substitution and thyroid hormone fluctuations were most marked in patients with multiple pituitary hormone deficiency (MPHD).

\section{DISCUSSION}

The interaction between GH and the thyroid axis can have a major implications for patients who commence GH therapy, particularly as the diagnosis of central hypothyroidism $(\mathrm{CH})$ relies mainly on circulating free T4 levels ${ }^{1}$. This is complicated by the fact that a free T4 concentration within the population reference range does not exclude $\mathrm{CH}$ and the performance of free T4 assays varies considerably, particularly at the lower end of the reference range.

As demonstrated in our study, free T4 levels decline with the $\mathrm{GH}$ replacement. However, the biological and clinical significance of this is unclear in the face of rising a freeT3 level. Our data demonstrate that ferritin, $\mathrm{Cu}$ and caeruloplasmin declined significantly following GH supplementation, suggesting reduced hepatic exposure to thyroid hormone.

The improvement in REE with GH replacement, reported by other investigators, was not observed in our study ${ }^{2}$. This may have been due to declining tissue exposure to thyroid hormone.

Complex alterations in lipid profile, including a rise in large HDL particles and Lp (a) may have been attributable to alteration in exposure to thyroid or growth hormone, or both.

We conclude that growth hormone replacement does not improve the biological actions of thyroid hormone in adults hypopituitary patients. 